\title{
RDUS
}

Revue de DROIT

UNIVERSITÉ DE SHERBROOKE

Titre : $\quad$ LAMENTING THE DISAPPEARANCE OF PRAGMATISM : SUBSIDIES LAW AFTER THE URUGUAY ROUND

Auteur(s): $\quad$ Lara FRIEDLANDER

Revue : $\quad$ RDUS, 1994-1995, volume 25, numéro 1-2

Pages: $\quad 287-315$

ISSN : $\quad 0317-9656$

Éditeur : $\quad$ Université de Sherbrooke. Faculté de droit.

URI : $\quad$ http://hdl.handle.net/11143/12915

DOI : $\quad$ https://doi.org/10.17118/11143/12915 
Page vide laissée intentionnellement. 


\title{
ARTICLE
}

\section{LAMENTING THE DISAPPEARANCE OF PRAGMATISM : SUBSIDIES LAW AFTER THE URUGUAY ROUND}

\author{
by Lara FRIEDLANDER ${ }^{*}$
}

L'adoption des Accords dits de la phase d'Uruguay démontre de façon significative le passage du GATT de l'orientation pragmatique à l'approche légaliste. Les subventions qui constituent un aspect de plus en plus controversé du commerce international sont parmi les mesures affectées par ce changement d'orientation. Ainsi, par exemple, au lieu de l'ancienne méthode dite de deux voies, la légalité des subventions dans le cadre du GATT sera maintenant établie principalement par des tests de spécificité et de préjudice. L'auteure prétend que 1'Accord de la phase d'Uruguay portant sur les subventions aura pour effet d'affaiblir le GATT, les pressions domestiques forçant les États à en ignorer les dispositions. Elle suggère donc que la réforme du droit applicable aux subventions aurait avantage à recourir à l'usage de la clause d'invalidation ou d'affaiblissement des avantages tirés des concessions commerciales. Puisque cette clause fait sentir la contrainte de la réciprocité, elle amène les États à se comporter en prenant pour acquis que les autres États observent également leurs engagements; du même coup, cette clause possède une légitimité supérieure à celle des Accords de la phase d'Uruguay. Or, une telle légitimité est cruciale lorsque la viabilité même de l'ordre juridique international dépend de son respect par chacun des États.

1. LL.B., University of Toronto. Student-at-law, McMillan Binch. I would like to thank Professor Michael Trebilcock for his helpful comments and suggestions. 
Acceptance of the Uruguay Round Agreements marks a significant reorientation of the GATT from pragmatism to legalism. Not least among the measures affected by this shift is subsidies, an increasingly controversial area of trade law. Unlike the previous Track 1/ Track 2 method, GATT-legality of subsidies will be now be determined primarily by specificity and injury tests. This paper argues that the Uruguay Round Agreement on subsidies will eventually undermine the GATT as domestic pressures force states to ignore GATT rules. The paper goes on to suggest that subsidies law reform should concentrate on encouraging the use of the nonviolation nullification and impairment provision. As nonviolation nullification and impairment facilitates reciprocity by regulating reliance-induced behaviour, its legitimacy is stronger than that of the Uruguay Round Agreements. Such legitimacy is crucial when the viability of an international legal order depends on self-enforcement. 


\section{TABLE OF CONTENTS}

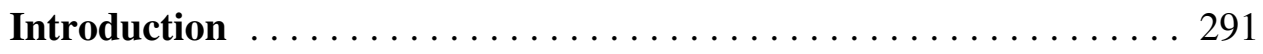

Subsidies . . . . . . . . . . . . . . . . . . . . . . . . 292

a) Subsidies Law Before the Uruguay Round . . . . . . . . . . 292

b) The Uruguay Round . . . . . . . . . . . . . . 296

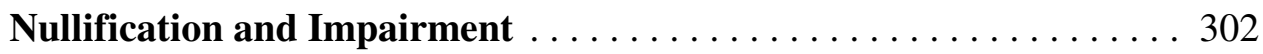

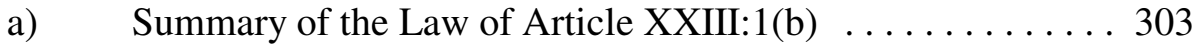

b) Effectiveness of Article XXIII:1(b) ........... 307

\section{Nullification and Impairment and the Uruguay Round Agreement}

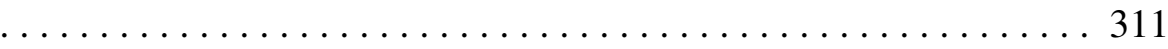

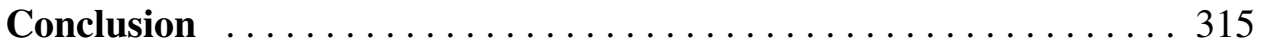




\section{Introduction}

Underlying the many battles that have been fought during the Uruguay Round of negotiations on the General Agreement on Tariffs and Trade (GATT) ${ }^{1}$ is one major theme : the transformation of the GATT into a rules-oriented world legal order. The dialectic between a negotiation-oriented, pragmatist model and a legalist, rules-oriented model has existed from the very inception of the GATT $^{2}$. In 1950, the pragmatist model prevailed : proposals for the International Trade Organization (ITO) were defeated by American protection of state sovereignty ${ }^{3}$. The momentum of the legalist model has increased over the past forty-five years ${ }^{4}$, as complaints of weakness in the GATT regime have accumulated $^{5}$. Many of the elements of the Uruguay Round Agreements ${ }^{6}$, such as the creation of an appelate body and the augmentation of surveillance functions, reflect this trend.

Acceptance of the Uruguay Round Agreement in December, 1993 marks a profound re-orientation of the GATT. This paper will argue against this legalistic shift and will posit instead that the vision of the GATT as a diplomatic instrument should have been strengthened. It will assert these propositions in

1. 61 Stat. A3, T.I.A.S. No. 1700 at 47, 55 U.N.T.S. 187.

2. See for example J. Jackson, The World Trading System : Law and Policy of International Economic Relations, Cambridge, Mass., MIT Press, 1989, at 299-308; J.M. Lutz, «GATT Reform or Regime Maintenance : Differing Solutions to World Trade Problems», (1991) 25:2 J. of World Trade 107; J. Carlson, «Hunger, Agricultural Trade Liberalization and Soft International Law : Addressing the Legal Dimensions of a Political Problem», (1985) 70 Iowa L.R. 1187; R.E. Hudec, «GATT Dispute Settlement After the Tokyo Round : An Unfinished Business», (1980) 13 Cornell Int'l L.J. 145.

3. R. Howse and M.J. Trebilcock, International Trade : Legal Order and Political Economy, (unpublished manuscript, 1993), c.1 at 36.

4. H.J. Cheetham, «The Federal Government Proposals for Reform of the GATT Dispute Settlement System : Continued Momentum for a Rules-Oriented Approach to Dispute Settlement in International Trade Agreements», (1991) 22 R.G.D. 431 at 432.

5. V.C. Price, «New Institutional Developments in GATT», (1992) 1 Minn. J. Global Trade 87 at 90; R.E. Hudec, Enforcing International Trade Law: The Evolution of the Modern GATT Legal System, Salem, New Hampshire, Butterworth, 1993, at 362; R.Z. Lawrence \& R.E. Litan, «The World Trading System After the Uruguay Round», (1990) 8 Boston U. Int'l L.J. 247 at 251; Howse and Trebilcock, supra, note 3, c. 15 at 28-9.

6. Final Act Embodying the Results of the Uruguay Round of Multilateral Trade Negotiations : Agreement on Subsidies and Countervailing Measures, 15 December, 1993, MTN/FA, UR-930246 [Hereinafter «Uruguay Agreement»]. 
the context of subsidies, a contentious branch of GATT law which has spawned many of the complaints referred to above ${ }^{7}$. It will argue that the new agreement on subsidies represents an attempt to impose a legalist framework on a mixture of legalist and pragmatist substance. Finally, this article will draw conclusions from the application of the new approach to the subsidies context, and attempt to generalize about the future of the GATT as a legal order.

\section{Subsidies}

\section{a) Subsidies Law Before the Uruguay Round}

Initially, the GATT provisions regarding subsidies were somewhat sparse. Article VI of the GATT prohibited the use of any export subsidy, direct or indirect, with the exception of subsidies for primary products. Subsidies on primary products only violated the GATT if they resulted in an inequitable share of world trade. There was no remedial provision other than Article XVI which merely required notification and consultation.

A more aggressive subsidies regime did not appear until the Tokyo Round. The Subsidies $\operatorname{Code}^{8}$ was a compromise between two views on the regulation of subsidies : the «injury-only» school and the «anti-distortion» school ${ }^{9}$. The injury-only school contends that subsidies are not harmful by definition. They can help correct market distortions and support economic and political goals which are distinct from economic efficiency. Therefore trade remedies should only be used when injury is caused to the domestic production industry of another state. The anti-distortion school reasons that all subsidies are bad because they reduce productive and distributive efficiency. The result of the compromise between these two views was a two-track approach. The first track,

7. Subsidies complaints comprised approximately $38 \%$ of GATT litigation up to and including 1989. Hudec, supra, note 5 at 339.

8. Agreement on Interpretation and Application of the Articles VI, XVI and XXIII of the General Agreement on Tariffs and Trade, (1980) 26 BISD 56; 31 U.S.T. 513; T.I.A.S. No. 9619 [hereinafter «Subsidies Code»].

9. J.H.J. Bourgeois, «The GATT Rules for Industrial Subsidies and Countervailing Duties in the New GATT Round - The Weather and the Seeds» in The New GATT Round of Multilateral Negotiations : Legal and Economic Problems, E. Petersmann \& M. Hilf (eds.), Deventer, Netherlands, Kluwer Law and Taxation Publishers, 1991, 219 at 231-2. 
Article 4 of the Subsidies Code, allowed states to impose countervailing duties on export subsidies, as long as the aggrieved party could show the existence of a subsidy, material injury and a causal link between the subsidy and the injury. In contrast, Article 11 merely allowed a state to request consultations with any other party when an export subsidy existed or when any subsidy appeared to be causing harm to a domestic industry. No other specific remedial provisions were contemplated.

The two track approach to subsidies caused much concern among trade theorists, as well as among the GATT's member states. A basic source of contention was the vagueness of the definition of a subsidy. The GATT divided subsidies into countervailable export subsidies and other subsidies, but gave no definition of either term. A list in the Annex to the Code prohibited certain subsidization schemes such as direct subsidies contingent upon export performance and currency retention schemes involving export bonuses, but the list was merely «illustrative and non-exhaustive» ${ }^{10}$. The GATT had developed a fairly effective legal framework for export subsidies ${ }^{11}$, yet had been unable to find an equivalent principle for domestic subsidies. The reason for this is clear: it is difficult to discover a legitimate domestic policy justification for an export subsidy. However, many domestic subsidies have legitimate policy justifications : long-term economic stability, infant industries, religious preferences, lifestyle preferences and preservation of traditional work patterns are just a few examples $^{12}$. The legitimacy of domestic subsidies is recognized in the very text of the General Agreement. Although Article XVI notes that domestic subsidies can be harmful to other states' interests and distort trade, it also states that domestic subsidies are «widely used as important instruments for the promotion of social and economic policy objectives such as employment sustenance, restructuring of certain economic sectors and re-training» ${ }^{13}$. According to Depayre and Petriccione, the intellectual difficulty of finding an umbrella principle which covers an almost endless variety and degree of government policies and the diversity of political attitudes on what should be considered a

10. Article XI:3.

11. Bourgeois, supra, note 9 at 228.

12. Jackson, supra, note 2 at 19-20.

13. Article XI:1. 
legitimate subsidy have resulted in an inability to define an actionable subsidy ${ }^{14}$. Despite the widespread use of subsidies world-wide, the number of rulings against subsidies has been remarkably low ${ }^{15}$. The lack of clarity of a definition of subsidies has made an effective regulation regime impossible and has significantly decreased incentives to reduce or eliminate subsidies.

A second criticism of the current approach to subsidies centers on the GATT's dispute settlement mechanism. One consequence of the Track 1/Track 2 approach has been excessive reliance on countervailing duties (CVDs) ${ }^{16}$. Although there have been numerous complaints concerning countervailing duties, particularly in the past decade, the success rate of these complaints, both in terms of panel decisions and settlements, has been extremely low ${ }^{17}$. Hudec has speculated that CVD cases are inherently more likely to fail given the «typical arbitrariness of AD/CVD criteria and the legal rigidity of measures once taken ${ }^{18}$.

CVDs themselves are not inherently undesirable remedies. With attention to overcompensation, a countervailing duty is often preferable to other trade remedies such as export taxes and export quotas which may increase trade distortion. As Hufbauer and Erb suggest, «the remedy can prove worse than the original subsidy» ${ }^{19}$. In fact, the use of CVDs by the United States has resulted in trade liberalization in that the removal of foreign trade barriers outnumbered American retaliatory restrictions ${ }^{20}$.

14. G. Depayre and R. Petriccione, «Definition of Subsidy» in Subsidies and International Trade : A European Lawyers' Perspective, J.H.J. Bourgeois (ed.), Deventer, the Netherlands, Kluwer Law and Taxation Publishers, 1991, 67.

15. Hudec, supra, note 5 at 345.

16. Lawrence \& Litan, supra, note 5 at 252.

17. Hudec, supra, note 5 at 338-9, 346-7 and 355.

18. Ibid. at 355. Note that «AD» refers to «Anti-Dumping».

19. G.C. Hufbauer and J.S. Erb, Subsidies in International Trade, Washington, Institute for International Economics, 1984, at 112-3.

20. J.M. Finger, «That Old GATT Magic No More Casts Its Spell (How the Uruguay Round Failed)», (1991) 25:2 J. World Trade 19 at 20. 
Rather, it is the unilateral nature of past usage of countervailing duties which has caused concern ${ }^{21}$. Under Track 1, a state could impose countervailing duties without prior authorization from a GATT panel ${ }^{22}$. Thus, barring a GATT complaint, the content and frequency of application of countervailing duty law is determined entirely by domestic legislation. The result is a debilitation of the GATT. Since CVDs bring domestic control within GATT-legality, they «have a magic all their $\mathrm{own} \gg^{23}$, reducing or eliminating the incentive to use multilateral GATT procedures. As Meng states, Track 1 was «more predictable, timely and effective ${ }^{24}$. Therefore, although Track 1 and Track 2 were not mutually exclusive options, the incentive for strong economies to negotiate through the GATT was all but destroyed.

Futhermore, although Track 1 mechanisms were available to all members of the GATT, realistically they were only available to economically powerful states. For example, threats by Madagascar to reduce American access to the Madagascar market would not be terribly effective. Even the possibility of using countervailing duties against economic powerhouses can result in other types of trade restraints, such as voluntary export restrictions (VERs) or orderly marketing arrangements (OMRs). The result is that some states, particularly developing ones, see the countervailing duty as a new form of non-tariff barrier $^{25}$.

Finally, not only did the Track 1/Track 2 system weaken the GATT and limit effective remedies to strong economies, it provided remedies for only a portion of all subsidies. Subsidies can be categorized into different groups according to their distortionary effects. A can subsidize its exports into B, thereby harming B's domestic producers. A can subsidize its exports into C, thereby displacing

21. K. Kautzor-Schroder, «Subsidies and Countervail in the Uruguay Round : A Comment» in The New GATT Round of Multilateral Negotiations : Legal and Economic Problems, E. Petersmann and M. Hilf (eds.), Deventer, Netherlands, Kluwer Law and Taxation Publishers, 1991, 237 at 239.

22. Subsidies Code, supra, note 8 , art. 4(4).

23. Finger, supra, note 20 at 20.

24. W.P. Meng, «Comment» in Subsidies and International Trade : A European Lawyers' Perspective, J.H.J. Bourgeois (ed.), Deventer, the Netherlands, Kluwer Law and Taxation Publishers, 1991, 175 at 177.

25. Lawrence \& Litan, supra, note 5 at 253. 
B's producers who also export to C. A can subsidize its domestic industries, thereby harming B's producers who export to A. Of these three types of subsidies, only the first type was countervailable under the Subsidies Code. The other types had to be pursued through Track 2. Thus, as Bourgeois argues, «while the importing contracting party can protect itself by countervailing measures, other contracting parties whose exporting interests may be affected are left out in the cold» ${ }^{26}$.

Given the gravity of these problems, it is no surprise that the Subsidies Code never received much support from GATT members : as of June 1989 only 24 states (the EC countries being one state) had signed on to the agreement.

\section{b) The Uruguay Round}

The Uruguay Round Agreement categorizes subsidies into «prohibited», «actionable» and «non-actionable» groups (also known as the white/grey/black or green/amber/red approach). Prohibited subsidies include listed export subsidies, subsidies contingent upon export performance or local sourcing and other subsidies such as some of the ones listed in the Code's Annex which are obviously intended to give aid to exports ${ }^{27}$. The rationale here is that such subsidies betray motives of trade distortion rather than legitimate domestic policy actualization ${ }^{28}$. Non-actionable subsidies are at the opposite end of the spectrum, being those subsidies which cannot be attacked with trade remedies. These are subsidies which are generally available (not «specific») or which are identified by the Agreement as non-actionable, such as some research and development activity ${ }^{29}$. Determination of whether or not a subsidy will be specific will be done through the application of a specificity test of the type currently used in the United States. If a subsidy is deemed specific, then it will be actionable. A subsidy is specific if it is overtly so (i.e. if the legislation is clearly targetting specific enterprises or industries), if it is theoretically available

26. Bourgeois, supra, note 9 at 229.

27. Uruguay Round Agreement, supra, note 6, art. 3.

28. J.J. Barceló, «Subsidies, Countervailing Duties and Antidumping after the Tokyo Round», (1980) 13 Cornell Int. L. J. 257 at 282-285.

29. Uruguay Round Agreement, supra, note 6, art. 8.2(a). 
to everyone but in fact only used by a few producers or if government discretion indicates that certain producers have been targetted ${ }^{30}$.

In the middle category are actionable subsidies. A subsidy will be deemed actionable if it is specific and causes «adverse effects» to other states. Adverse effects are defined as :

«(a) injury to the domestic industry of another signatory

(b) nullification or impairment of benefits accruing directly or indirectly to other Members under the GATT 1994, in particular the benefits of concessions bound under Article II of the GATT 1994

(c) serious prejudice to the interests of another Member.» ${ }^{31}$

Should a state believe that a prohibited or actionable subsidy is causing harm to its domestic producers, it can take one of two approaches. The state may request consultations and, if the consultations fail, may request consideration by a pane $^{32}$. Unilateral action in the form of a countervailing duty is also available to the complainant state, so long as the complainant member has made reasonable attempts at consultations and so long as the subsidized imports are causing injury ${ }^{33}$.

There is one distinctly positive element of the Uruguay Round Agreement. Clarification of the definition of subsidies reduces the uncertainty of possible unilateral or multilateral response. In contrast to the vague thresholds of the Subsidies Code, the tests in the Agreement are specific enough to enable governments and economic actors to plan at least some subsidization without fear of trade retaliation ${ }^{34}$. Fears over the possible vulnerability of broad social

30. Ibid., art. 2.1.

31. Ibid., art. 5.1.

32. Ibid., art. 4 and 7.

33. Ibid., art. 19.

34. J. Jackson, «Strengthening the International Legal Framework of the GATT-MTN System : Reform Proposals for the New GATT Round» in The New GATT Round of Multilateral Negotiations : Legal and Economic Problems, E. Petersmann and M. Hilf (eds.), Deventer, Netherlands, Kluwer Law and Taxation Publishers, 1991, 3 at 7-8. 
policies such as health care or education should be alleviated and even the fear of unilateral trade remedies should be somewhat decreased in view of the opportunity to present evidence ${ }^{35}$.

However, the classification system proposed in the Uruguay Round Agreement does not clearly address the underlying, more complex issue in subsidies law : the determination of the «legitimacy» of a domestic subsidy by an international tribunal. The crux of the problem is this : domestic subsidies are important if not crucial aspects of domestic politics ${ }^{36}$. This has long been acknowledged by the GATT itself ${ }^{37}$. An international organization which purports to regulate domestic subsidies therefore must have some basis for determining which subsidies are legitimate and which subsidies should be exposed to retaliation. Normally, the GATT is competent to make decisions based on basic trade theory. Trade theory reasons that subsidies cause economic distortions. They transfer production from efficient to inefficient producers, thereby raising the price consumers pay for products ${ }^{38}$. Consumers lose again because they must pay tax dollars to fund subsidies. It has been suggested that states which import subsidized goods should send a «thank-you note» to the exporting state ${ }^{39}$. Since comparative advantage tells us that free trade is always more beneficial to trading states than distorted trade ${ }^{40}$, a GATT panel could make a legitimacy decision based on its own area of expertise : trade theory and practice.

However, as with other areas of trade law (such as intellectual property), trade theory can be an inadequate basis for decision-making regarding domestic subsidies. It is not clear, for example, that an unelected international panel with no expertise outside trade law should decide whether or not to strike down a subsidy which affects a product's price by a relatively small smount, yet achieves

35. Uruguay Round Agreement, supra, note 6, art. 12.1.

36. Bourgeois, supra, note 9 at 221.

37. As noted above, the preamble and article 8.1 of the Subsidies Code state that «subsidies are used by governments to promote important objectives of national policy».

38. Howse \& Trebilcock, supra, note 3 , c. VI at 31.

39. Jackson, supra, note 2 at 251; M. Trebilcock, «Throwing Deep : Trade Remedy Laws in a FirstBest World» in M.J. Trebilcock and R.C. York (eds.), Fair Exchange, Toronto, C.D. Howe Institute, 1990, 235 at 242.

40. See chapter 1, pp. 3-5 in Howse \& Trebilcock, supra, note 3. 
a significant national objective, such as enabling a traditional community to maintain its historical way of life. If states could agree on a list of legitimate subsidies, the institutional competence of a GATT panel would not be in doubt. Yet, as Kautzor-Schroder suggests, it is unlikely that states would be able to agree on such a list ${ }^{41}$. Hudec has stated that

«The regulatory impact of GATT rules has rested on the normative force of organized community condemnation. The key to the force of such normative pressures is an underlying consensus among GATT member governments about what constitutes correct governmental behavior.» ${ }^{42}$

Given the difficulty of reaching consensus on the legitimacy of a particular subsidy, the force of a panel decision is thus reduced.

The Agreement's response to this problem is puzzling. First, the heart of the Agreement, the categorization of prohibited, non-actionable and actionable subsidies, amounts to a legal framework which presupposes that the legitimacy of subsidies can be definitively determined. At first glance the fact that most contentious subsidies could be actionable makes the Agreement's categorization uncontroversial. However, a closer look shows that even this apparently uncontroversial attempt to impose legal rules on subsidies is problematic. For example, a subsidy which is partially contingent on use of domestic goods over imported goods will be prohibited by article 3.1(b) regardless of the subsidy's potential positive domestic economic, social or political impact.

The use of the specificity test to determine which subsidies are nonactionable is questionable as well. The decision to label non-specific subsidies as non-actionable is intuitively sensible as such subsidies normally do not produce significant distortion ${ }^{43}$. However, this goal can be accomplished by simply requiring a minimum level of adverse effects of a subsidy before a GATT panel will consider authorization of retaliation or other measures. This approach is already embodied in article 5.1 of the Agreement. Furthermore, specificity is not always a guarantee that protectionist interests are at work. For example,

41. Kautzor-Schroder, supra, note 21 at 240-1.

42. Hudec, supra, note 2 at 150.

43. Jackson, supra, note 2 at 267. 
the United States imposed countervailing duties on Canadian softwood lumber in 1986. However, the fact that Canadian firms have supported lower stumpage fees than those in effect in the United States may have only been a reflection of Canada's industrial structure ${ }^{44}$. Jackson suggests that there is another justification for specificity. Specificity eliminates from the trade regulation arena policies, such as health care, policing and education which we intuitively believe should be excluded from its scope ${ }^{45}$. Thus the specificity test, as it is applied to determine which subsidies are non-actionable, is also a legitimacy test. This type of test is of particular concern given the possibility of unilateral retaliation.

Second, the same legalistic approach to legitimacy occurs in article 5 of the Agreement which addresses actionable subsidies. As said above, article 5.1 states that a subsidy is actionable if it causes injury, nullification and impairment and serious prejudice to another signatory. Should a subsidy satisfy these criteria, the Agreement states that the offending state «shall take appropriate steps to remove such adverse effects or shall withdraw the subsidy» ${ }^{46}$. If the subsidy is not removed within 6 months, then the Committee on Subsidies and Countervailing Measures will authorize countermeasures ${ }^{47}$. Thus the Agreement represents a rejection of the Tokyo Round Track 2 conciliation approach in favour of specific rules which can determine with some certainty the legality of a subsidy. The Agreement is overt in its legalistic approach and does not betray any sense of institutional incompetence. Note the almost constitutional tone of the phrase «No signatory should cause...adverse effects to the interests of other signatories» in article 5.1.

It is my argument that the Agreement's legalistic approach to subsidies will be harmful to the future of GATT. Even well-drafted rules may be ignored at times. A state may choose to ignore international rules for two reasons. First, domestic needs are sometimes more important than international obligations.

44. A.D. Anderson, «An Analysis of the Proposed Subsidies Code Procedures in the 'Dunkel Text' of the GATT Uruguay Round : The Canadian Exporters' Case», (1993) 27 J. of World Trade 71. Anderson acknowledges that the Dunkel Draft attempts to account for differences in the extent of diversification of economic activities, yet is skeptical about its implementation. See text at 745 .

45. Jackson, supra, note 2 at 267-8.

46. Uruguay Round Agreement, supra, note 6, art. 7.8.

47. Ibid. 
A government may ignore the GATT in favour of finding solutions to serious domestic problems. As Hudec points out,

«Trade restrictions are the product of underlying economic problems, and they are "inevitable" as long as the problems are not solved. The mere existence of rules will not make these economic subsidies disappear, nor will rules promote the kind of discussion needed to understand and solve them.» ${ }^{48}$

The GATT may also be ignored by governments which face severe domestic political pressure from certain industries, interest groups or political parties ${ }^{49}$. The controversy in Canada during the 1988 election over the Free Trade Agreement and its potential impact on Canadian jobs is but one example of the strength of anti-free trade domestic pressure. Although an international regulatory system will exert some external pressure on governments ${ }^{50}$ it is inevitable that without an enforcement mechanism bound to happen these two types of domestic pressure will sometimes prevail over the GATT.

Given that even well-crafted rules will undoubtedly be disregarded by individual states at times, an excessively legalistic GATT will eventually lose its effectiveness. If the sole reason why GATT members used subsidies in the past was the vagueness of the Tokyo Round reforms, then the more precise Uruguay Round Agreement would be more effective in eliminating subsidies. However, as Lutz has argued, the implicit assumption of legalism that faulty rules are responsible for protectionism is incorrect since violations of the GATT are more likely to take place in reaction to economic problems and not before economic problems appear ${ }^{51}$. As it is inevitable that GATT members will sometimes ignore the General Agreement, then making the General Agreement

48. R.E. Hudec, «GATT or GABB? The Future Design of the General Agreement on Tariffs and Trade», (1971) 80 Yale L.J. 1299 at 1307.

49. Hudec, supra, note 2 at 159.

50. Long has stated that «the very existence of GATT law can have important side-effects. Governments are likely to be more hesitant about taking unlawful trade measures when they know the rules are there, and that they may well come under heavy criticism for their action in an international forum.» O. Long, Law and its Limitations in the GATT Multilateral Trade System, Dordrecht, Martinus Nijoff Publishers, 1985, at 64. See also Price, supra, note 5; Carlson, supra, note 2 at 1197-99.

51. Lutz, supra, note 2 at 113-4. 
more detailed or more strict will not improve compliance and certainty, and will only accentuate the rejection of the Agreement. Repeated evasion of GATT rules would weaken the legitimacy of the GATT itself. As long as the GATT does not have its own enforcement mechanism, it must seek to find rules which achieve some certainty without encumbering itself with the risks of constitutional pretensions. I will argue below that the concept of nullification and impairment realizes this goal.

\section{Nullification and Impairment}

The GATT provision on nullification and impairment is found in Article XXIII. It states, in part :

1. If any contracting party should consider that any benefit accruing to it directly or indirectly under this Agreement is being nullified or impaired or that the attainment of any objective of the Agreement is being impeded as a result of

(a) the failure of another contracting party to carry out its obligations under this Agreement, or

(b) the application by another contracting party of any measure, whether or not it conflicts with the provisions of this Agreement, or

(c) the existence of any other situation,

the contracting party may, with a view to the satisfactory adjustment of the matter, make written representations or proposals to the other contracting party of parties which it considers to be concerned...

2. If no satisfactory adjustment is effected between the contracting parties within a reasonable time, or if the difficulty is of the type described in paragraph 1(c) of this Article, the matter may be referred to the CONTRACTING PARTIES. The CONTRACTING PARTIES shall promptly investigate the matter...and shall make appropriate recommendations...If the CONTRACTING PARTIES consider that the 
circumstances are serious enough to justify such action, they may authorize a contracting party or parties to suspend the application to any other contracting party or parties of such concessions or other obligations under this Agreement.

Nonviolation nullification and impairment (Article XXIII:1(b)) is different from the rest of the GATT in that it represents a distinctly pragmatic approach to trade regulation. Unlike violation nullification and impairment in XXIII:1(a), 1(b) contemplates compensation or reaction to a trade measure without the categorization of that measure as GATT-illegal ${ }^{52}$. Because of its emphasis on compensation rather than punishment ${ }^{53}$, it seeks not to judge state conduct, but to preserve trade relationships by emphasizing equity and predictability. It is this emphasis, it will be argued, that makes Article XXIII:1(b) a desirable alternative to the Uruguay Round approach to subsidies.

\section{a) Summary of the Law of Article XXIII:1(b)}

On its face, 1(b) appears too broad to be effective. This has certainly been a complaint of many commentators ${ }^{54}$. Certainly the jurisprudence has been sparse. Of the 26 complaints which put 1(b) forward as a ground up until the end of 1989, a detailed analysis of 1(b) was only made ten times. However, it is submitted that this jurisprudence is sufficient to provide an analytical basis for subsidy complaints which currently fall under 1(b), as well as a basis for expansion of the application of this concept to all subsidy questions.

Early GATT panels developed a two-pronged test to determine whether nonviolation nullification and impairment had occurred. The first prong of the test is whether or not the complainant party had a «reasonable expectation» that the impugned trade measure would not be introduced. The second prong of the

52. W.J. Davey, «Dispute Settlement in GATT», (1987) Fordham Int'l L.J. 51 at 56-7.

53. J. Jackson, World Trade and the Law of GATT, New York, Bobbs-Merrill, 1969, at 171.

54. See, for example, J. Jackson, «Governmental Disputes in International Trade Relations : A Proposal in the Context of GATT», (1979) 13 J. of World Trade 1 at 7 and J.M. Waincymer, «Revitalizing GATT Article XXIII - Issues in the Context of the Uruguay Round», (1988) 12 World Competition 5 at 33-4. See also R.E. Hudec, «Retaliation Against 'Unreasonable' Foreign Trade Practices : The New Section 301 and GATT Nullification and Impairment», (1975) 59 Minn. L.R. 461 for a review of the drafting history of XXIII:1(b). 
test examines whether or not the trade measure has significantly changed competitive conditions. Evidence of material injury is not necessary. This analytical framework was established in a 1949 complaint by Chile against Australian subsidies on ammonium sulphate. During World War II, Australia subsidized both sodium nitrate and ammonium sulfate. Australia then negotiated a tariff concession with Chile on sodium nitrate. In 1949 Australia lifted the subsidy on sodium nitrate but continued the subsidy on ammonium sulphate. The result was that Australian ammonium sulphate absorbed Chile's sodium nitrate market. The Working Party stated that the actions of the Australian government «could not reasonably have been anticipated» by Chile and, moreover, that Chile «had reason to assume» that the subsidy on ammonium sulphate would not be removed before the removal of subsidies on other products $^{55}$. The Working Party was careful to state that the reasonable expectation would not apply to all subsidies; it was applied because the two products were so similar and the initiation and implementation history of the subsidies on each product was equally similar.

In the Norwegian Sardines case ${ }^{56}$, Norway and Germany had negotiated tariff concessions in 1951 on Scandinavian sardines. However, soon after the tariff concession, Germany granted more favourable treatment to Portugese sardines. The GATT panel supported Norway's claim of nullification and impairment on the grounds that Germany's actions had «substantially reduced» the value of Norway's concessions and that Norway had reason to believe that its product would not be treated less favourably than products from other states. The panel held that Norway's expectations were reasonable because equality of treatment was discussed during the tariff negotiations and that tariff concessions were in fact exchange.

The framework established in the Ammonium Sulphate and Norwegian Sardines cases has been vigorously affirmed. In the Import Duties on Starch and Potato Flour case, a GATT panel found that Benelux tariff concessions to Germany were undermined by Germany's failure to carry out its obligations ${ }^{57}$.

55. (1952) 2 BISD 188 at 193.

56. General Agreement on Tariffs and Trade, Basic Instruments and Selected Documents, vol. 2, Geneva, GATT, 1952, at 188-196.

57. (1955) 3 BISD 77. 
A 1955 report by a GATT Working Party affirmed the principle that GATT members which have negotiated concessions under Article II have, absent evidence to the contrary, a reasonable expectation that the value of their concessions will not be impaired by subsequent trade measures ${ }^{58}$. Attempts by the European Economic Community to weaken the jurisprudential value of the Norwegian Sardines case and the Ammonium Sulphate case have been squarely rejected by GATT panels ${ }^{59}$. More general use of nullification and impairment has received some support among academics as well ${ }^{60}$.

The two early cases are an explicit rejection of fault-based judgment by GATT panels. In the Ammonium Sulphate case, Australia's policy was intended to support sugar farmers by increasing their income through the subsidization of ammonium sulphate. The panel report recognized the legitimacy of the policy, and specifically stated that it had

«no intention of implying that the action taken by the Australian Government was unreasonable, but simply that the Chilean Government could not have reasonably been expected during the negotiations in 1947 to have foreseen such action or the reasons which led to it.» ${ }^{61}$

Furthermore, although the panel recommended a change in Australia's subsidy policy as the most practical solution, it emphasized that its power was limited to the authorization of compensatory trade measures on the part of Chile. The panel was careful to respect Australia's sovereignty and not to substitute its own policy determinations. As Petersmann states, «the GATT rules on nonviolation complaints rightly recognize the various «GATT freedoms» of contracting parties to introduce trade measures not prohibited by GATT even if they nullify and impair the competitive benefit of previous trade concessions ${ }^{62}$. This

58. (1955) 3 BISD 224.

59. See the Oilseeds case, (1988) 37 BISD 86, described below.

60. See Hudec, supra, note 48 at 1374-5.

61. Supra, note 55 at 194.

62. E.-U.Petersmann, «Violation Complaints and Non-violation Complaints in Public International Trade Law», (1991) German Yearbook of Int'l Law 175 at 227. This sentiment was also echoed in the Oilseeds case, below, where the panel wrote that «[t] he recognition of the legitimacy of an expectation relating to the use of production subsidies therefore in no way prevents a contracting party from using production subsidies consistently with the General Agreement; it merely 
respect for sovereignty is perhaps reflected in the fact that although Australia wrote a dissenting opinion, the panel report was adopted by the contracting parties in March of $1950^{63}$.

Mark Sills ${ }^{64}$ has argued that the spirit of Norwegian Sardines and Ammonium Sulphate has been significantly diluted by more recent GATT panel decisions, especially the series of complaints launched by Uruguay in $1961^{65}$. The complaints were directed at 15 different countries with respect to 30 different products or groups of products, including a complaint added on later against the European Economic Community's CAP (the Common Agricultural Policy). However, Uruguay's position was remarkably unclear. No specific legal theory was enunciated, with the exception of one reference to Article XIII:1(c). No statistical information was provided to the panel. Uruguay did not even specify which type of retaliation it wished the panel to authorize. The panel gave recommendations for certain violations of the GATT which had been admitted by the defendant states, yet refused to give any ruling on the subject of nonviolation nullification and impairment.

Sills argues that the Uruguay case indicates a «decidedly more conservative approach to the issue of the effect of impairment of the benefits of a GATT concession without actual breach of a GATT obligation» because the panel «demonstrated some reluctance to make use of [the concept of nonviolation nullification and impairment] without proof based on statistical or other evidence of trade impairment ${ }^{66}$. Yet it is hardly surprising that a GATT panel would refuse to make a ruling without any specific legal argumentation or evidence. Surely the Uruguay complaints are not a signal of a decline in the potency of Article XXIII, but rather represent the analytical rigor expected by GATT panels.

delineates the scope of the protection of a negotiated balance of concessions.» See infra, note 59 at 129.

63. GATT/CP.5/SR.6 (6 November 1950).

64. M.N. Sills, «The Concept of Non-Violation Nullification and Impairment in the Investment and Services Chapters of the Canada-US Free Trade Agreement», (1990) 3 R.I.B.L. 127.

65. (1963) 11 BISD 95.

66. Sills, supra, note 64 at 134. 


\section{b) Effectiveness of Article XXIII:1(b)}

It is my argument that nonviolation nullification and impairment is a more effective legal tool in the international context than more legalist processes. I base this statement on two principles. The first principle is that nonviolation nullification and impairment facilitates dialogue and negotiation. This is illustrated by three controversial GATT cases : Canned Fruit, Citrus and Oilseeds.

In the 1981 Canned Fruit complaint, the United States opposed a subsidy to EC producers based on the calculation of the difference in the selling price of domestic and imported processed fruit (a part of the EC's Common Agricultural Policy (CAP)). The panel found that the subsidy constituted nonviolation nullification and impairment, rejecting the EC defence that XXIII:1(b) required proof of causation ${ }^{67}$. However, the panel report was never adopted, in part due to the EC's objection to the panel's decision on proof of causation, and the Canned Fruit case is now cited by some as evidence of the GATT's failure as an effective legal instrument. ${ }^{6}$

The panel report in the Citrus case ${ }^{69}$ was also blocked from adoption. In that case, the United States lodged a complaint regarding EC tariff preferences to citrus fruits from certain Mediterranean countries pursuant to a series of trade agreements negotiated in the 1960s and 1970s. The crux of the dispute was the question of whether the Mediterranean agreements constituted regional trade blocs in conformity with Article XXIV. The panel chose not to address the GATT-legality of the agreements directly, ruling instead, in an extremely long and convoluted report, that American benefits had been nullified and impaired by the preferences. The result was EC blockage of adoption of the report by the Council and a series of tariff increases by the United States and the EC over the coming months. Like the Canned Fruit case, the Citrus case was a highly visible example of the apparent failure by the GATT to regulate trade relations effectively ${ }^{70}$.

67. GATT Doc. L/5778 (20 February 1985).

68. Hudec, supra, note 5 at 157.

69. GATT Doc. L/5776 (7 February 1985).

70. Hudec, supra, note 5 at 161. 
The last case in the trilogy is the Oilseeds case, an action initiated by the United States in 1988 against EC subsidies to oilseed crushing mills. The United States and the EC had negotiated a series of tariff concessions, including tariffs on oilseeds, at the time of the creation of the CAP in the early 1960s. However, in the mid-1980s, the EC increased its output of subsidized oilseeds. The panel ruled that the subsidies constituted both a violation of Article III: 4 of the GATT and nonviolation nullification and impairment. The EC registered reservations to the ruling, but did not block its adoption in January of 1990, pledging to work toward removal of the subsidies in the future ${ }^{71}$. In late 1991 the EC redirected the subsidies from crushing mills to oilseed farmers. The United States initiated another GATT complaint. Again the panel ruled that nonviolation nullification and impairment was occurring, but this time the EC blocked adoption of the report ${ }^{72}$. Negotiations between the United States and the EC continued into the fall of 1992 at which point the United States declared a discriminatory tariff on various EC imports. The case seems to have been settled by an exchange of concessions during the Uruguay Round.

Are these three cases fatal to the concept of nullification and impairment? It is my argument that Canned Fruit, Citrus and Oilseeds actually represent the success of nonviolation nullification and impairment as a trade regulation tool. In all three cases, the results of a violation ruling would have had an enormous impact. In Canned Fruit, a ruling by the panel in favour of the United States would have endangered the entire Common Agricultural Policy ${ }^{73}$. In Citrus, a ruling by the panel in favour of the United States would have endangered all preferential tariff arrangements between the EC and Mediterranean states ${ }^{74}$. In Oilseeds, a huge market for oilseeds was in issue ${ }^{75}$. Although these two arrangements may well have been GATT-illegal, they were complex, deliberate, important domestic policy. The European Community was not prepared to accept the domestic consequences of the destruction of these policies; political pressure was already strong enough to induce the EC to block adoption of

71. Supra, note 59.

72. Hudec, supra, note 5 at 247-8.

73. Ibid. at 155 .

74. Ibid. at 158 .

75. In 1962, American oilseed exports to the EC were valued at approximately $\$ 8-10$ billion. In the 1988 complaint, the United States claimed \$1.5-2 billion in lost trade. See Hudec, ibid. at 559. 
findings of nonviolation nullification and impairment. By choosing to rule on nonviolation nullification and impairment rather than on specific violations, the panel rulings gave some legitimacy to American retaliation, increasing external pressure on the EC to take action and avoiding the anarchy of auto-interpretation. Yet by not forcing the EC to make a clear choice between GATT legality and its domestic policies, the rulings also enabled the EC to «save face» and gave the Community more room to negotiate. All three cases were eventually settled. Considering the immense impact of the policies at stake, the role of the GATT in promoting their settlement should be upheld as one of qualified success rather than total failure. Perhaps this success would not have been achieved had the panels loudly proclaimed the GATT-illegality of Europe's policies $^{76}$.

A good example of the consequences of more judgmental GATT rulings is the DISC case. Here, the European Community claimed that American tax laws amounted to export subsidies. The panel found a violation of article XVI: $4^{77}$ yet their finding was followed by years of litigation, consultation and retaliation. Although the panel report was finally adopted in November of 1981 (five years later), total compliance never occurred. The case has been thus described as «the largest and most conspicuous failure in the history of GATT litigation» ${ }^{78}$. Authors such as Hudec have argued that the panel's violation ruling may have actually been harmful to the negotiations because it served to make the bargaining positions of both parties more rigid $^{79}$.

Canned Fruit, Citrus and Oilseeds show that nonviolation nullification and impairment can facilitate implementation of GATT goals with less risk than

76. The Dollar Area Quotas case is an example of the influence of a GATT panel which refuses to decide the basic issue. In this case, the United States complained about British quantitative restrictions in favour of Caribbean states. Although the panel refused to make a legal finding, it gave a detailed decision. The parties settled the matter in the following year. See (1974) 20 BISD 230 and Hudec, supra, note 5 at 189. As panels cannot consistently refuse to make legal findings in hard cases, non-violation nullification and impairment is plausible alternative.

77. (1977) 23 BISD 98.

78. Hudec, supra, note 5 at 59.

79. Hudec, supra, note 2 at 166, footnote 61. See K.M. Harris, «The Post-Tokyo Round GATT Role in International Trade Dispute Settlement», (1983) 1 Int'1 Tax and Bus. Lawyer 142 at 150 for an alternative interpretation. 
violation litigation. However, nonviolation nullification and impairment also enjoys a principled justification which more legalistic rules do not. Article XXIII:1(b) protects reliance interests. As Hudec explains,

«The purpose of the nullification and impairment remedy is to preserve the balance of the original exchange of values. If a particular disadvantageous measure is foreseen, the country receiving concessions will be able to discount the possibility in advance by paying a lesser value for the concessions affected. If that is so, then the actual occurrence of the foreseen disadvantage will not upset the balance, for it already will have been taken into account. Conversely, if the disadvantageous measure is not anticipated, the country receiving the concessions is more likely to pay full value and thus to suffer an imbalance when the commercial advantage is later reduced.» ${ }^{80}$ [emphasis in original]

Reasonable expectations are based on the behaviour of states themselves. Most of the cases refer to expectations derived from negotiated tariff concessions, but the panel in the German Import Duties on Starch case held that expectations could originate from official diplomatic acts as well ${ }^{81}$. Since reasonable expectations are based on the behaviour of states themselves, it is states which establish normative boundaries of their behaviour, not substantive GATT rules. Since the values at stake in nonviolation nullfication and impairment litigation are the consistency and reliability of the diplomatic conduct of GATT members rather than the validity of the substance of their policies, a GATT panel decision on nonviolation nullification and impairment increases legitimacy. Compliance with past trade concessions is essential to the continued existence of the GATT. A GATT panel, as the representative body of the member states and as a body with expertise in GATT law, is the most appropriate arena for determining whether or not compliance with previous concessions has occurred. This sense of legitimacy was articulated in the first Oilseeds panel ruling :

80. R.E. Hudec, «Retaliation Against «Unreasonable» Foreign Trade Practices : The New Section 301 and GATT Nullification and Impairment», (1975) 59 Minn. L.R. 461 at 487.

81. Supra, note 57. As described above, the Benelux states lodged a complaint against Germany, arguing that Germany had not lived up to its commitment to reduce specific tariffs. These commitments included concessions in the formal tariff schedule as well as a letter from the German delegation to the Benelux delegation promising new reductions. The panel found that the letter was sufficient to have given the Benelux delegation reasonable expectations of German action, despite the fact that the concessions were not officially included in the tariff schedule. 
«[contracting parties] must therefore be assumed to base their tariff negotiations on the expectation that the price effect of the tariff concessions will not be systematically offset. If no right of redress were given to them in such a case they would be reluctant to make tariff concessions and the General Agreement would no longer be useful as a legal framework for incorporating the results of trade negotiations.. ${ }^{82}$

Therefore the theoretical justification for nonviolation nullification and impairment is much more pragmatic than realistic. Under Article XXIII:1(b), the GATT is not a set of normative rules regarding legitimate international behaviour, but a set of procedures to induce negotiations and ensure their effectiveness. Considering the difficulty of finding legal rules to regulate subsidies, the pragmatism of nonviolation nullification and impairment is a preferable approach to the subsidies question.

\section{Nullification and Impairment and the Uruguay Round Agreement}

At first glance, the Agreement appears to support the use of nonviolation nullification and impairment to regulate subsidies. As mentioned above, article 5.1 lists nullification and impairment of benefits as one of three indicators of an actionable subsidy. The footnote to article 5.1(b) states that nullification and impairment «shall be established in accordance with the practice of application of Article XXIII:1(b) of the General Agreement» ${ }^{83}$. Thus a plausible interpretation is that a subsidy will be actionable when it could not have been reasonably expected by the complaining state and when it alters the balance of benefits and obligations between states.

However, under article 5.1, injury and serious prejudice to member states also indicate an actionable subsidy. Injury and serious prejudice are legal rules in the more classic sense. The «injury test» has been called a «pillar of trade policy» ${ }^{84}$ and has long been used in the antidumping context ${ }^{85}$ The injury test maintains that a subsidy on exports will be actionable if it causes material injury

82. (1989) 37 BISD 86 at $128-9$.

83. Uruguay Round Agreement, supra, note 6, art. 5.1(b), footnote 2.

84. Jackson, supra, note 2 at 5 .

85. GATT, supra, note 1 , article VI. 
to the domestic producers of a like product. If the subsidy can be shown to cause material injury, then article 11.2 of the Agreement allows the complainant state to impose countervailing duties. Serious prejudice is a broader indicator which focusses on effect more than causation. Although it is mentioned in both the General Agreement and the Subsidies Code ${ }^{86}$, serious prejudice remains a somewhat undeveloped concept. It refers generally to a specific level of harm to the domestic market, harm to exports to states with subsidized domestic production and harm to exports which have been displaced in third markets by subsidized goods. The Agreement imposes more detailed requirements on the serious prejudice test, including a 5\% ad valorem subsidization level and the use of market share to measure displacement of a product ${ }^{87}$.

Both the injury and serious prejudice tests represent the legalist view of GATT. Should a subsidy cause a certain level of harm, it will be deemed actionable. The Agreement's solution to the issue presented early in this article, the competence of the GATT to evaluate the legitimacy of domestic policies, is a unilateral judgment in favour of anti-distortion.

Jackson recommends that GATT values should be balanced with domestic policy goals by a material injury test. This is logical from a state sovereignty perspective; why should foreign states have influence over subsidization in other states if they themselves are not affected ${ }^{88}$ ? However, such a view ignores the fact that GATT rules do not flow from long-standing principles of natural justice; they are a culmination of complex negotiations. The GATT is not a constitution; it is still merely a series of contracts from which parties can withdraw at any time ${ }^{89}$. As such, states should be able to protect their

86. Articles XVI and VIII respectively.

87. Uruguay Round Agreement, supra, note 6, articles 6.1 and 6.4.

88. Jackson, supra, note 2 at 263.

89. This should not be a surprising statement. It is difficult to give any international laws «constitutional» status. Even jus cogens norms (transcendent, immutable norms) in public international law, limited to only a small number of principles such as self-determination and prohibition of genocide, are not always above controversy. See Oppenheim's International Law, (R. Jennings \& A. Watts, eds.), Harlow, England, Longman Group, 1992, at 7-8.

Note, of course, that there are significant costs to withdrawing from the GATT structure; it is my argument that it is avoidance of these costs that drive adherence to trade rules and not theoretical principles which would be relied upon to drive a more constitutional structure. 
investment, whether or not the state has experienced material injury or merely opportunity cost. Certainly complainant states should not be forced to wait until the damage has already been done ${ }^{90}$. Conversely, the GATT should not protect states from harm due to subsidization when there was no indication that the subsidizing state was ever willing or actually able to eliminate the subsidy ${ }^{91}$.

This mixture of legalist and pragmatist triggers of a legalist outcome in the Uruguay Round Agreement is theoretically inconsistent. Nonviolation nullification and impairment seeks to maintain reciprocity within limits set by states themselves; injury and prejudice tests maintain specific standards of free trade within absolute substantive, quantifiable limits. Nonviolation nullification and impairment protects reliance-induced conduct to strengthen existing concessions $^{92}$; injury and prejudice tests protect producers regardless of reliance or of political feasibility. Nonviolation nullification and impairment is compensatory; injury and prejudice tests are punitive.

Nullification and impairment seems to be an additional indicator of an actionable subsidy, yet it is unclear what kind of role it is intended to play. Explication of violation nullification and impairment has relied on the existence of violations of the GATT and therefore would appear unhelpful as an element of the very test which attempts to determine which subsidies are GATT violations. Explication of nonviolation nullification and impairment seems equally unhelpful : as shown above, examination of reasonable expectations and changes in competitive conditions is not compatible with injury and serious prejudice tests. In all likelihood, nullification and impairment will be glossed over as litigants concentrate on the better known and understood injury and prejudice components. Nonviolation nullication and impairment, not only

90. Oilseeds, supra, note 59 at 130.

91. Some authors, such as Anderson, have even argued that the material injury test makes «very little economic sense» (supra, note 44 at 90). Article 15.5 of the Uruguay Round Agreement states that the subsidy does not have to be the sole cause of the injury. This is rational choice since a sole cause test would make it extremely difficult to find GATT violations but it also means that «no economic assessment has been undertaken to determine the relevance of the size of the subsidy on the requisite injury caused to the domestic industry.» (ibid.). Anderson calls this «a major victory for protectionists». (ibid.). See also H. Huang, E. Krakar and I.H. Uhm, «The InjuryCausality Test Under Canadian Trade Remedy Law», (1993) 27 J. of World Trade 117.

92. Petersmann, supra note 62 at 225. 
within the Subsidies Agreement and but also as a separate cause of action, will probably continue to be virtually ignored by GATT members.

The result of such a mix of theoretical approaches is the loss of the benefit of the pragmatic approach underlying nonviolation nullification and impairment. The legitimacy of GATT panel decisions as well as their role as facilitators of negotiated solutions and guardians of good faith compliance in GATT have been annulled by the legalistic approaches of the injury and serious prejudice tests ${ }^{93}$.

\section{Conclusion}

The Uruguay Round Agreement is an ambitious attempt to impose a predictable legal order on a group of sovereign states with a panoply of different interests. It represents a reaction of decades of complaints of the impotence of the GATT in the face of recalcitrant nations. However, the drafters seem to have lost sight of the basic glue of any international order : self-interest.

«Codes are rules that apply between sovereign states and enforcement must rely on recognition of a self-interest in seeing the rules work...A balance of selfinterest holds the GATT together. The possibility that (a) specific trade benefits given to a country will be removed through trade retaliation and/or (b) the system as a whole will only stand a limited amount of disregard to agreed rules before it comes crashing down are strong incentives to follow the rules.» ${ }^{94}$

GATT reform should emphasize the value of the GATT, especially in light of past criticisms of its weakness. It should portray the GATT as a mechanism which encourages reciprocity and good faith by increasing external pressure on states to keep their promises. Reform should also avoid the brinksmanship associated with strengthening rules which are difficult for states to follow

93. Some may argue that this theoretical inconsistency has existed since the inception of the Subsidies Code, which lists injury, nullification and impairment and serious prejudice as evidence of adverse effect as well. However, as these concepts are found in rarely-used Track 2 portion of the Code (Article VIII), the results of any inconsistencies would have been negligible.

94. R.B. Rivers and J.D. Greenwald, «The Negotiation of a Code of Subsidies and Countervailing Measures : Bridging Fundamental Policy Differences», 11 Law and Pol'y in Int'l Bus. 1447 at 1488. 
consistently and aim to establish rules which are realistic and effective. Nonviolation nullification and impairment accomplishes these goals.

However, the result of the new legalistic approach of the Uruguay Round may have permanently buried pragmatism. As the legalistic approach is a reaction to the perceived failure of pragmatism, the failure of the new rulesoriented GATT may only lead to a stronger push for legalism. Efforts to strengthen reciprocity and good faith would be replaced by the establishment of a «Super-GATT» or a «GATT-plus» arrangement whereby trade liberalization would only occur in a specific sector or between lesser numbers of states ${ }^{95}$. Such an arrangement would be a radical departure from the current orientation towards inclusiveness of developing nations and different sectors and may feed the «growing dissatisfaction with multilateral trade negotiations...as a means of achieving trade liberalization ${ }^{96}$. Centralized, unaccountable decision-making might also raise fears of a democratic deficit similar to that experienced by the European Community ${ }^{97}$. By rejecting the pragmatic approach, the GATT has chosen a new set of problematic questions which will only escalate in complexity and difficulty.

95. See Lawrence \& Litan, supra, note 5 at 266-8 for a discussion of this option.

96. C.A. Primo Braga \& A.J. Yeats, «Multilateral and Managed Trade in the Post-Uruguay Round World», (1994) 3 Minn. J. Global Trade 231 at 233.

97. See R. Howse \& B. McGregor, «Annex III : Economic Integration in the European Community and Lessons for Canada» in R. Howse, Economic Union, Social Justice and Constitutional Reform: Towards a High But Level Playing Field, North York, Ontario, York University Centre for Public Law and Public Policy, 1992, at 169-170 and J. Pinder, «The European Community, the Rule of Law and Representative Government : The Significance of Intergovernmental Conferences», (1991) Gov't \& Opposition 199 at 204. 